\title{
The Proposed Conceptual Model for Investigating Moderating Effects of Contextual Factors on Supply Chain Management Practice-Performance Link in Malaysian Small and Medium Enterprises
}

\author{
Thoo Ai-Chin (Corresponding author) \\ Department of Management, Faculty of Management and Human Resource Development \\ Universiti Teknologi Malaysia \\ UTM Johor 81310, Malaysia \\ Tel: 60-12-258-1935 E-mail: acthoo@utm.my \\ Abu Bakar Abdul Hamid \\ Department of Management, Faculty of Management and Human Resource Development \\ Universiti Teknologi Malaysia \\ UTM Johor 81310, Malaysia
}

Tel: 60-17-768-7436 E-mail:m-abakar@utm.my

Huam Hon-Tat

Department of Management, Faculty of Management and Human Resource Development Universiti Teknologi Malaysia

UTM Johor 81310, Malaysia

Tel: 60-12-791-0455E-mail:drhuamht@gmail.com

Rohaizat Baharun

Department of Management, Faculty of Management and Human Resource Development Universiti Teknologi Malaysia

UTM Johor 81310, Malaysia

Tel: 60-7-553-1823 E-mail: m-rohaizat@utm.my

Rosman Md Yusoff

Department of Management, Faculty of Management and Human Resource Development Universiti Teknologi Malaysia

UTM Johor 81310, Malaysia

Tel: 60-19-751-3233 E-mail: dr_rosman@utm.my

Amran Rasli

Department of Management, Faculty of Management and Human Resource Development Universiti Teknologi Malaysia

UTM Johor 81310, Malaysia

Tel: 60-7-553-1800 E-mail:m-amran@utm.my

Received: February 9, 2011

doi:10.5539/ijbm.v6n12p135
Accepted: July 5, 2011 Published: December 1, 2011

URL: http://dx.doi.org/10.5539/ijbm.v6n12p135 
The research was financed by Research University Grant (GUP) of Universiti Teknologi Malaysia.

\begin{abstract}
Small and medium enterprises (SMEs) are playing an increasingly important role in sustaining economic growth and generating employment in Malaysia. SMEs also play a very crucial role in supply chain management (SCM) as they may serve the roles of suppliers, producers, distributors and customers. However, adoption of SCM in Malaysian SMEs has not been broadly explored. Therefore, the authors propose a conceptual model by examining the moderating effects of contextual factors (firm size, firm age and supply chain length) on the relationship between SCM practices, namely, information sharing, strategic supplier partnership, customer relationship, material flow management, corporate culture and SCM performance in a single study. The study has important managerial implications as the findings will enable management of SMEs to understand progressive and highly varied SCM practices and contextual factors that contribute to the SCM performance and its effective implementation.
\end{abstract}

Keywords: SMEs, SCM practice, SCM performance, Contextual factors, Malaysia

\title{
1. Introduction
}

In today's increasingly globalised economy, SMEs are now considered to be the major source of dynamism, innovation and flexibility in emerging and developing countries, as well to the economies of most industrialised nations. They contribute substantially to the economic development and employment generation (OECD, 2006; Koh, Demirbag, Bayraktar, Tatoglu, \& Zaim, 2007). SMEs form as the potential economic back-bone of many regions and make a large contribution to employment than large firms (World Employment Report, 2004-05; Peng, 2009). A similar trend exists in Malaysia too where SMEs have potential to be a powerful engine growth and innovation with the constitution of $99.2 \%$ businesses (RMK-10, 2011). The Malaysian SMEs are distributed in the four broad economic segments: services, manufacturing, basic raw materials producers and agriculture (Hashim, 2007).

In recent years, the importance of SMEs has attracted increasing attention from academia and researchers (Ellegaard, 2006). Despite the increased interest in SMEs, it appears that literature does not offer much SCM studies in SMEs (Quayle, 2003; Thakkar, Kanda, \& Deshmukh, 2009). As indicated by Hong and Jeong (2006), SMEs play a very crucial role in SCM as they may play the pivotal roles of suppliers, manufacturers, retailers, distributors or even customers. They may supply raw materials, manufacture products and deliver finished goods to end customers (Huin, Luong, \& Abhary, 2002). There has been widespread dissemination of studies supporting the fact that SCM is an effective tool to gain competitive advantage (Mentzer, 2004; Hassini, 2008; Ambe, 2010). Many companies have begun to identify that today competition occurs between supply chains networks rather than individual firms (Li, Subba Rao, Ragu-Nathan, \& Ragu-Nathan, 2005; Koh et al., 2007). Companies that practice SCM have reported significant improvements in individual supply chain functions ranging from 10 to $80 \%$ (Wagner, Fillis, \& Johansson, 2003). The results of Deloitte's study (2003), which includes responses from nearly 600 companies in 22 countries around the world, also indicated that profit margins are $73 \%$ higher for manufacturers who excel in SCM, as compared to companies with poor SCM performance. Furthermore, research by Edgell Communications (2003) revealed that companies employ advanced SCM practices are approximately $40 \%$ more profitable and have a $1 \%$ to $2 \%$ advantage in total supply chain costs than other companies.

Despite the growing importance of SCM, it is evident that SMEs in Malaysia still lack a strong awareness of practicing effective SCM concepts. Recent survey by United Parcel Service Inc (UPS) (2008) revealed that more than $80 \%$ of Malaysian SMEs did recognise the importance of supply chain efficiency, but majority (42\%) are still experimenting with various ways to manage their supply chain. Malaysian SMEs focus simply on reducing transportation and distribution costs. They see supply chain management as a means to cut cost and a method for quality assurance and control through visibility of the supply chain. This issue is also identified in a study of 627 New Zealand manufacturers who are unable to take full advantage of newer concepts of SCM, albeit there is awareness of the SCM initiatives among the manufacturers (Basnet, Corner, Wisner, \& Tan, 2003). Besides, based on a study of 288 UK SMEs, Quayle (2003) revealed that there is lack of effective adoption of SCM techniques such as e-commerce, new technology, kaizen and research and development (R\&D). Surprisingly, lower priority is given to these innovations techniques that necessary for effective implementation of the SCM concepts.

Many empirical studies have focused primarily on proposing and testing SCM strategic models. Tan (2002) suggested that a seamless supply chain includes six SCM practices: supply chain integration, supply chain characteristics, information sharing, strategic location, customer service management and Just-in-time (JIT) capability. Chow et al. (2008) combined the studies of Tan (2002) and Anderson, Britt, and Fayre (1997) by using customer and supplier management, supply chain features, communication and speed, and information 
sharing to represent SCM practices for US; integration and customer service management and supply chain features for Taiwan. Chen and Paulraj (2004) identified seven supply chain construct consisting of supply network structure, long-term relationship, supply base reduction, communication, cross-functional teams, supplier involvement and logistic integration to measure SCM. Chin, Rao Tumala, Leung, and Tang (2004) employed five success factors, namely building customer-supplier relationships, implementing information and communication technology, re-engineering material flows, creating corporate culture and identifying performance measurement to examine the current SCM practices of Hong Kong manufacturers. Min and Mentzer (2004) determined a set of SCM concepts to include agreed vision and customer focus, information sharing, risk and rewards sharing, cooperation, process integration, long-term relationships and agreed supply chain leadership. Tracey, Fite, and Sutton (2004) used technology utilisation (internal and supply chain technology usage), internal relationships (participative leadership, manufacturing and logistics participation in strategy), external relationships (supplier selection, evaluation and management), product development, transportation and inventory management (inventory control, warehousing and packaging) to represent SCM assimilation in their study. Wong, Arlbjorn, and Johansen (2005) attempted to reveal SCM practices for toy retailers in Europe which encompass supply chain performance, SCM initiatives, product uniqueness, lead-time and inventory-cost management, postponement and customisation, information sharing and coordination, supplier and customer relationships, information sharing and coordination, retail strategy, and distribution and logistics. Robb, Xie, and Arthanari (2008) used customer and supplier relationships, e-commerce and enterprise software to explore the relationship between supply chain practices and corporate performance.

The literature largely addresses only the internal functions, upstream suppliers or downstream customers of the supply chain. Therefore, in attempting to reflect the overarching of SCM concept, Li et al. (2005) developed and validated a measurement instrument for six SCM practices constructs which cover internal supply chain processes (internal lean practices and postponement), upstream (strategic supplier partnership), downstream (customer relationship), and supply-chain information flows (information sharing and information quality). Burgess, Singh, and Koroglu (2006) proposed a set of seven SCM constructs as including leadership, intra- and inter-organisational relationships, logistics, process improvement orientation, information system, business results and outcomes. Koh et al. (2007) identified a list of twelve SCM practices which includes building dense relationships with suppliers and customers, implementing inventory management including JIT and safety stock approaches, using inter-organisational systems such as e-procurement, engaging third-party services through 3PL, outsourcing and subcontracting, and managing internal side of the supply chain via strategic planning, supply chain benchmarking and managing the numbers of suppliers (few or many suppliers) for SMEs in Turkey.

While many literatures that do exist on the topic concentrates on construct of SCM practices, scant evidence is available on the actual successful SCM implementations and their relationship to firms' performance (Tan, 2002; Basnet et al., 2003; Li et al., 2005; Power 2005). Moreover, they failed to include contextual factors, such as firm size, firm age, firm's position in the supply chain and supply chain length, as these factors may influence the implementation of SCM practices (Li et al., 2005; Koh, et al., 2007). In order to implement a holistic approach to SCM, the practices, contextual factors and performance should be considered in combination or holistically. In terms of the firm size, the larger organisations may have higher levels of SCM practices since they usually have more resources for SCM implementation ( $\mathrm{Li}$ et al., 2005). For firm's position in the supply chain, Cook et al. (2011) examined the moderating effect of supply chain role (manufacturer, distributor, retailer or service provider) on the relationship between supply chain practices and performance, and they found that the supply chain role for a company makes a difference in terms of the specific supply chain practices that lead to better performance. Finally, overall there is limited empirical evidence on contextual factors that may be used by Malaysian SMEs in determining relationships between SCM practices and SCM performance. As pointed out, although considerable research has been devoted to the relationship between SCM practices and performance of large firms, rather less attention has been paid to the SCM practices and role of contextual factors in SMEs, particularly in Malaysia. Therefore, this study has extended previous research on determinants of supply chain performance (Thoo, Huam, Md Yusoff, \& Rasli, 2010) and previous researches conducted in western countries (Li et al., 2005; Cook et al., 2011) by viewing the contextual factors as moderating factors in determining the relationship between specific SCM practices and performance of Malaysian SMEs. Furthermore, SMEs planning to adopt SCM practices would also be able to applied strategies based on the proposed framework from this study.

\section{Literature Review}

\subsection{Constructs of SCM practices}

SCM practices include a set of approaches and activities utilised by an organisation to effectively integrate supply and demand for improving the management of its supply chain (Li et al., 2005; Wong et al., 2005; Koh et al., 2007). Based on the extant literature of SCM practices and examination of Malaysian SMEs, five constructs 
of SCM practices are identified and defined in this study to explore their impacts on SCM performance. The five constructs include information sharing, customer relationship, strategic supplier partnership, material flow management and corporate culture.

\subsubsection{Information sharing}

Information sharing is defined as making relevant data and information available to one's supply chain members (Lee \& Whang, 2000). Information is shared at strategic, tactical and operation level (Mentzer, 2004), mostly pertinent to demand, forecast, inventory level, sales, consumer information and capacity (Baihaqi, Beaumont, \& Sohal, 2008; Yu, Ting, \& Chen, 2010). Information sharing generates significant benefits for supply chain partners. Yu, Yan, \& Cheng (2001) explored that information sharing among supply chain partners can mitigate or eliminate the negative effect of bullwhip, centralise supply chain control, reduce inventory level and cost, and improve inventory decision making. Also, information sharing can reduce costs and increase customer service level (Yu et al, 2010). For instances, sharing of real-time inventory information allows Wal-Mart retail suppliers to monitor inventory levels and to plan replenishment, hence reducing the supply chain wide costs and optimising the SCM efficiency (Fawcett, Osterhaus, Magnan, Brau, \& McCarter, 2007). Dell receives transparent and accurate information from its suppliers about their capacities, inventories levels, quality measures and costs to enhance visibility to orders; Dell shares information with suppliers on forecasts, demand, sales and customer requirements to meet market demand (Bidgoli, 2004). Remarkable surge in the availability of shared information has enabled firms to accelerate the speed of decision making on SCM activities (Yu et al., 2001; Williamson, Harrison, \& Jordan, 2004; Cantor \& Macdonald, 2009).

Many studies have advocated the importance of information sharing across the supply chain. Min and Mentzer (2004) viewed information sharing as part of supply chain integration. Li, Ragu-Nathan, Ragu-Nathan, and Subba Rao (2006) and Li and Lin (2006) analysed the characteristics of information sharing from quantity and quality perspective. Also, their study found that information sharing as one of five SCM practices that generate a powerful effect on competitive advantage and organisational performance. Similarly, Zhou and Benton (2007) have explored the relationship aspect by examining supply chain practice together with information sharing and supply chain performance. Uusipaavalniemi and Juga (2009) have discussed the essential contribution of information technology is the reduction in information lead-time and improvement in the timing of information sharing. Wong et al. (2005) pointed out that implementation of contemporary supply chain initiatives can be enhanced by sharing information with trading partners in complementary activities. Sharing of information and knowledge with suppliers, customers and competitors has offered the forward-looking enterprises the advantages of creating a collaborative supply chain (Ketikidis, Koh, Dimitriadis, Gunasekaran, \& Kehajova, 2008; Bayraktar, Demirbag, Koh, Tatoglu, \& Zaim, 2009). According to Fawcett, Magnan, and McCarter (2008), transparent information sharing is the salient bridge to effective SCM, likewise the open flow of information between the upstream and downstream firms can sustain the competitive position of the firm (Humphreys, Lai, \& Sculli, 2001a).

\subsubsection{Strategic supplier partnership}

Strategic supplier partnership is development of a long-term relationship between firm and its suppliers (Li et al., 2006). Sustainable business success hinges more on working collaboratively with those supply chain partners (Spekman, Kamauff, \& Myhr, 1998; Alfred Wong, 2002). Therefore, a paradigm shift has emerged that extends from unproductive arm's-length supply chain relationship to long-term contracts (Humphreys, Shiu, \& Chan, 2001b; Chin et al., 2004). Effective partnership is dependent upon an environment grounded in mutual trust, loyalty, positive sum game, fairness in negotiations, goal and intent revelation, and commitment among partners (Chandra and Kumar, 2000). Good partnerships have regarded as strategic decisions in sharing of risks and benefits, reducing cost and continuous improvement in all spheres of their activities (Tumala, Philips, \& Johnson, 2006). Similarly, small businesses recognise that collaborative supplier partnership is the best way to connect external and internal expertise in innovation capability (Freel. 2000). Such strategic partnerships involve suppliers in decision-making and internal operations in key activities such as research and development, procurement and distribution (Bagchi, Ha, Skjoett-Larsen, \& Soerensen, 2005). Many organisations begin to reduce supplier base by partnering with a few key suppliers who are vital to the success of the organisations (Goffin, Szwejczewski, \& New, 1997). Key suppliers are integrated in new product development; through early supplier involvement, the organisations can reduce risk and cost, improve time-to-market and quality, and save development time (Eisto, Holtta, Mahlamaki, Kollanus, \& Nieminen, 2010). Various studies (Fearne \& Hughes, 2000; Humphreys et al., 2001b; Choy, Fan, \& Lo, 2003; Vereecke \& Muylle, 2006; Bartlett, Julien, \& Baines, 2007) have addressed the needs of close collaborative linkages with suppliers through the entire supply chain. According to Alfred Wong (2002), firms with a high supplier satisfaction and contribution achieve a higher level of customer satisfaction and supply chain performance outcomes than those that show weaker supplier value focus. 


\subsubsection{Customer relationship}

The nature of customer relationships have conceptualised along a continuum ranging from creating relationships (attraction), developing relationships (loyalty) to maintaining relationships (interaction) (Izquierdo, Cillan, \& Gutierrez, 2005). Customer relationship is aimed to manage customer complaints and expectations, improve customer satisfaction (Hoots, 2004; Bagchi et al., 2005), maximise customer loyalty and retention (Ngai, 2005; Leverin \& Liljander, 2006), reduce cost (Crosby, 2002; Hoots, 2004), increase profitability (Storbacka, Strandvik, \& Gronroos, 1994; Ngai, 2005) and build long-term relationships (Ravald \& Gronroos, 1996; Xu, Yen, Lin, \& Chou, 2002; Osarenkhoe \& Bennani, 2007). Collaborative relationships with customers normally revolve around trust building (Foster \& Cadogan, 2000), shared benefits and burden, long-term commitment and fair negotiation (Valsamakis \& Sprague, 2001). Strategic partnerships with customers enable organisations to fully cooperate with the most profitable customers. An empirical study of 203 manufacturing SMEs in Turkey provides support for the view that close partnership with customers is one of the most important SCM practices (Koh et al., 2007).

Customers participating in the initial stages of the development process can help to raise information about potential improvements and innovations (Lagrosen, 2005). Customers are involved in reference groups to provide suggestions and their product requirement. Many firms have begun to switch from a product-centric approach to a customer-centric approach (Xu et al., 2002), as now delivering superior customer value is becoming vital for the success of firms (Wang, Lo, Chi, \& Yang, 2004). The customer-centred approach, coupled with customer relationship management (CRM) software allows organisations to unite the relationship marketing strategies and information technology (IT) to develop mutually beneficial and valuable long-term relationships with customers and other key stakeholders (Dimitriadis \& Stevens, 2008).

\subsubsection{Material flow management}

The purpose of keeping and managing inventories of raw materials, work-in-process (WIP) and finished good is to serve as buffers between supply and demand processes (Williams \& Tokar, 2008). Therefore, an effective logistics network is imperative to ensure a smooth material flow between market and production (Chin et al., 2004), particularly for SMEs when they aim to improve their performance (Thakkar et al., 2009). The implementation of material flow management aims at reducing costs of non-value-adding efforts and the stocks while simultaneously achieving long-term sustainability (Spath \& Baumeister, 2001). There are a variety of partnering initiatives are being employed to encourage collaborative inventory management that involves inter-dependent trading partners, such as vendor managed inventory (VMI), efficient consumer response (ECR) and collaborative planning, forecasting and replenishment (CPFR) (Sari, 2007) with the hopes of mitigating bullwhip effect, minimising demand uncertainty, reducing costs and in the end improving profitability. For example, Childerhouse, Lewis, Naim, and Towill (2003) studied the best practices on how to re-engineering a construction supply chain by using material flow control system, providing examples of nine different companies. Thus, the development of creative solutions to material flow offers firms a high potential for realising new economic competitive advantages. In this context, logistic capability is expected to result in improved supply chain efficiency. The capabilities include timely materials delivery, global delivery capabilities, shipments accuracy and good knowledge of logistics (Meier, Williams, \& Singley, 2004).

\subsubsection{Corporate culture}

Corporate culture is defined as common expectations, practices and goals that are shared by the majority of the organisation (Deresky, 2008). SMEs suffer from lack of management talent and hinder by poor strategic vision (Thakkar et al., 2009); therefore, management support has become a critical factor for successful supply chain performance (Van Hoek, Chatham, \& Wilding, 2002). Meier et al. (2004) supported the importance of management support and pointed out that leadership management is an important element in the SCM. Leadership management requires shared culture, privacy protection, accountability, high management expertise, good mindset and professional, decisive in decision making, ethical and continuous performance measurement. Mello and Stank (2005) found that firms have inappropriate or inadequate cultural elements (e.g. shared assumptions, values and artifacts) are inclined to fail when adopting SCM practices. According to Fawcett, Ogden, Magnan, and Cooper (2006), a successful supply chain is driven by organisational commitment and governance. There are four types of managerial support required to achieve high supply chain performance: from upper management support to departmental support, channel support and infrastructural support. In a recently conducted survey (Sandberg \& Abrahamsson, 2010) among two retail companies, top management is essential for driving change management process; therefore they should function as supply chain thinker, relationship manager, controller and organiser for the future for successful SCM implementation.

\section{Proposed Conceptual Model}

In this study, a conceptual framework of SCM practices in a small to medium-sized manufacturers' supply chain was developed using earlier research in SCM, information management and manufacturing management as a 
theoretical foundation. While many theoretical and empirical literature have been widely studied the above SCM practices, however, to the best of the authors' knowledge, none of the previous studies had attempted to incorporate all the five practices of SCM implementation, namely, information sharing, strategic supplier partnership, customer relationship, material flow management and corporate culture into a single study. Moreover, none of the publications focusing specifically on contextual factors (firm size, firm age and supply chain length) on the relationship between SCM practices and performance. The SCM performance include increased in sales, high costing accuracy, high coordination between departments, and high suppliers and customers collaboration (Koh et al., 2007). The framework of the proposed conceptual model is shown in Figure 1 :

The following hypotheses are formulated based on the above addressed issues:

H1: Information sharing has a positive impact on SCM performance.

$\mathrm{H} 2$ : Strategic supplier partnership has a positive impact on SCM performance.

H3: Customer relationship has a positive impact on SCM performance.

H4: Material flow management has a positive impact on SCM performance.

H5: Corporate culture has a positive impact on SCM performance.

H6: Contextual factors (firm size, firm age and supply chain length) moderate the relationship of SCM practices and SCM performance.

\section{Research Methodology}

Preliminary analysis of the target population will come from all establishments and entrepreneurs registered with the Small and Medium Industries Development Corporation (SMIDEC) in the manufacturing sector. Systematic sampling is employed to select a sample from the lists of SMEs registered under SMIDEC. To meet the objectives of this study, a questionnaire is developed to measure and assess SMEs' attitudes toward the practices of SCM. The questionnaire is targeted to be completed by a senior officer/executive in charge of SCM practices. Reliability analysis is used to test the internal consistency of the instrument. The internal consistency reliability will be higher if the Cronbach's alpha is closer to 1 (Sekaran, 2003). For each of the items scales, exploratory factor analysis (EFA) is used to explore the possible underlying factor structure without imposing a preconceived structure on the outcome (Child, 1990). Multiple linear regression is used to analyse the relationship between a single dependent variable and the five independent variables in the study. Also, hierarchical regression model is applied to examine the moderating effect or impact of contextual factors on the relationship between SCM practices and performance.

\section{Conclusion}

The proposed model presents a framework for SMEs to use when determining whether their SCM practices including information sharing, customer relationship, strategic supplier partnership, material flow management and corporate culture have improved the organisational performance and profitability. The framework advocated above also allows SMEs to identify which contextual factors, namely firm size, firm age and supply chain length require attention so as to improve the level of SCM performance in Malaysian SMEs. Additionally, the testing of the model will provide SMEs with a guide for measuring the implementation of their SCM initiatives and highlighting the necessary changes required in present practices, as well as determines if improvements have occurred as a result of the adoption of SCM practices. However, as with most of research, this study has limitations. This study is narrowly concentrated on Malaysian manufacturing SMEs and a single respondent, thus the findings cannot be extended to all Malaysian SMEs in general. Future research should include a broader range of supply chain roles, such as suppliers, manufacturers, distributors and retailers across the supply chain, as well as multiple respondents from a single organisation. Furthermore, the proposed model reflects the lack of other practices such as cross-functional teams (Chen and Paulraj, 2004), risk and reward sharing (Min and Mentzer, 2004) and internal lean practices and postponement (Li et al., 2005). Future study should define SCM construct from wider and diverse perspectives by encompassing the above dimensions. Finally, in terms of theoretical contributions, this study is mainly given to the SCM field. In short, the study includes a more thorough explanation of information sharing, strategic supplier partnership, customer relationship, material flow management, corporate culture in SMEs' SCM practices. Other implications for SCM literature being discussed are that SCM practices, contextual factors and performance should be considered in combination for a successful SCM implementation.

\section{References}

Alfred Wong. (2002). Sustaining company performance through partnering with suppliers. International Journal of Quality \& Reliability Management, 19(5), 567-580. http://dx.doi.org/10.1108/02656710210427539 
Ambe, I. M. (2010). Agile supply chain: strategy for competitive advantage. Journal of Global Strategic Management, 7, 5-17.

Anderson, D. L., Britt, F. E., \& Favre, D. J. (1997). The seven principles of supply chain management. Supply Chain Management Review, 4(1).

Bagchi, P. K., Ha, B. C., Skjoett-Larsen, T., \& Soerensen, L. B. (2005). Supply chain integration: a European survey. International Journal of Logistics Management, 16(2), 275-294. http://dx.doi.org/10.1108/09574090510634557

Baihaqi, I., Beaumont, N., \& Sohal, A. (2008). Information sharing in supply chains: a survey of Australian manufacturing. International Review of Business Research Papers, 4(2), 1-12.

Barlett, P. A., Julien, D. M., \& Baines, T. S. (2007). Improving supply chain performance through improved visibility. The International Journal of Logistics Management, 18(2), 294-313. http://dx.doi.org/10.1108/09574090710816986

Basnet, C., Corner, J., Wisner, J., \& Tan, K-C. (2003). Benchmarking supply chain management practice in New Zealand. Supply Chain Management: An International Journal, 8(1), 57-64. http://dx.doi.org/10.1108/1359854031046336

Bayraktar, E., Demirbag, M., Koh, S. C. L., Tatoglu, E., \& Zaim, H. (2009). A causal analysis of the impact of information systems and supply chain management practices on operational performance: evidence from manufacturing SMEs in Turkey. International Journal Production Economics, 122, 133-149. http://dx.doi.org/10.1016/j.jpe.2009.05.011

Bidgoli, H. (2004). The internet encyclopaedia: volume 3. United States of America, New Jersey: John Wiley and Sons.

Burgess, K., Singh, P. J., \& Koroglu, R. (2006). Supply chain management: a structured literature review and implications for future research. International Journal of Operations \& Production Management, 26(7), 703-729. http://dx.doi.org/10.1108/01443570610672202

Cantor, D. E., \& Macdonald, J. R. (2009). Decision-making in the supply chain: examining problem solving approaches and information availability. Journal of Operations Management, 27, 220-232. http://dx.doi.org/10.1016/j.jom.2008.09.002

Chandra, K., \& Kumar, S. (2000). Supply chain management in theory and practice: a passing fad or a fundamental change? Industrial Management \& Data System, 100(3), 100-113. http://dx.doi.org/10.1108/02635570010286168

Chen, I. J., \& Paulraj, A. (2004). Towards a theory of supply chain management: the constructs and measurements. Journal of Operations Management, 22, 119-150. http://dx.doi.org/10.1016/j.jom.2003.12.007

Child, D. (1990). The essentials of factor analysis. (2nd ed.). London: Cassel Educational Limited.

Childershouse, P., Lewis, J., Naim, M., \& Towill, D. R. (2003). Re-engineering a construction supply chain: a material flow control approach. Supply Chain Management: An International Journal, 8(4), 395-406. http://dx.doi.org/10.1108/13598540310490143

Chin, K-S., Rao Tumala, V. M., Leung, J. P. F., \& Tang, X. (2004). A study on supply chain management: the Hong Kong manufacturing perspectives. International Journal of Physical Distribution \& Logistics Management, 30(6), 505-524. http://dx.doi.org/10.1108/09600030410558586

Chow, W. S., Madu, C. N., Kuei, C-H., Lu, M. H., Lin, C., \& Tseng, H. (2008). Supply chain management in the US and Taiwan: an empirical study. OMEGA: The International Journal of Management Science, 36, 665-679.

Choy, K. L., Fan, K. K. H., \& Lo, V. (2003). Development of an intelligent customer-supplier relationship management system: the application of case-based reasoning. Industrial Management \& Data Systems, 103(4), 263-274. http://dx.doi.org/10.1108/02635570310470665

Cook, L. S., Heiser, D. R., \& Sengupta, K. (2011). The moderating effect of supply chain role on the relationship between supply chain practices and performance: an empirical analysis. International Journal of Physical Distribution \& Logistics Management, 41(2), 104-134. http://dx.doi.org/10.1108/09600031111118521

Crosby, L. A. (2002). Exploding some myths about customer relationship management. Managing Service Quality, 12(5), 271-277. http://dx.doi.org/10.1108/09604520210442056

Deloitte Research. (2003). Mastering complexity in global manufacturing: powering profits and growth through value chain synchronization. Deloitte Research, New York, NY.

Deresky, H. (2008). International management: managing across borders and cultures. (6th ed.). Upper Saddle 
River, N.J.: Pearson Education, Inc.

Dimitriadis, S., \& Stevens, E. (2008). Integrated customer relationship management for service activities: an internal/external gap model. Managing Service Quality, 18(5), 496-511. http://dx.doi.org/10.1108/09604520810898857

Edgell Communications. (2003). The 2003 retail \& consumer goods shared strategy study. RIS Consumer Goods Technology, PRTM.

Eisto, T., Holtta, V., Mahlamaki, K., Kollanus, J., \& Nieminen, M. (2010). Early supplier involvement in new product development: a casting-network collaboration model. World Academy of Science, Engineering and Technology, 62, 856-866.

Ellegaard, C. (2006). Small company purchasing: a research agenda. Journal of Purchasing \& Supply Management, 12, 272-283. http://dx.doi.org/10.1016/j.pursup.2006.08.004

Fawcett, S. E, Ogden, J. A, Magnan, G. M \& Cooper, M. B. (2006). Organisational commitment and governance for supply chain success. International Journal of Physical Distribution \& Logistics Management, 36(1), 22 - 35. http://dx.doi.org/10.1108/09600030610642913

Fawcett, S. E., Magnan, G. M., \& McCarter, M. W. (2008). Benefits, barriers, and bridges to effective supply chain management. Supply Chain Management: An International Journal, 13(1), 35-48. http://dx.doi.org/10.1108/13598540810850300

Fawcett, S. E., Osterhaus, P., Magnan, G. M., Brau, J. C., \& McCarter, M. W. (2007). Information sharing and supply chain performance: the role of connectivity and willingness. Supply Chain Management: An International Journal, 12(5), 358-368. http://dx.doi.org/10.1108/13598540710776935

Fearne, A., \& Hughes, D. (2000). Success factors in the fresh produce supply chain: insights from the UK. British Food Journal, 102(10), 760-772.

Foster, B. D., \& Cadogan, J. W. (2000). Relationship selling and customer loyalty: an empirical investigation. Marketing Intelligence \& Planning, 18(4), 185-199. http://dx.doi.org/10.1108/02634500010333316

Freel, M. (2000). External linkages and product innovation in small manufacturing firms. Entrepreneurship and Regional Development, 12(3), 245-226. http://dx.doi.org/10.1080/089856200413482

Goffin, K., Szwejczewski, M., \& New, C. (1997). Managing suppliers: when fewer can mean more. International Journal of Physical Distribution \& Logistics Management, 27(7), 422-436. http://dx.doi.org/10.1108/09600039710188486

Hashim, M. K. (2007). SMEs in Malaysia: a brief handbook. Malaysia: August Publishing Sdn. Bhd.

Hassini, E. (2008). Building competitive enterprises through supply chain management. Journal of Enterprise Information Management, 21(4), 341-344. http://dx.doi.org/10.1108/17410390810888633

Hong, P., \& Jeong, J. (2006). Supply chain management practices of SMEs: from a business growth perspective. Journal of Enterprise Information Management, 19(3), 292-302. http://dx.doi.org/10.1108/17410390610658478

Hoots, M. (2004). Customer relationship management for facility managers. Journal of Facility Management, 3(4), 346-361. http://dx.doi.org/10.1108/14725960510630524

Huin, S., Luong, L., \& Abhary, K. (2002). Internal supply chain planning determinants in small and medium-sized manufacturers. International Journal of Physical Distribution \& Logistics Management, 32(9), 771-782. http://dx.doi.org/10.1108/09600030210452440

Humphreys, P. K., Lai, M. K., \& Sculli, D. (2001a). An inter-organizational information system for supply chain $\begin{array}{lllll}\text { management. International Journal Production Economics, } & 70, & \text { 245-255. }\end{array}$ http://dx.doi.org/10.1016/S0925-5273(00)00070-0

Humphreys, P. K., Shiu, W. K., \& Chan, F. T. S. (2001b). Collaborative buyer-supplier relationships in Hong Kong manufacturing firms. Supply Chain Management: An International Journal, 6(4), 152-162. http://dx.doi.org/10.1108/EUM0000000005708

Izquierdo, C. C., Cillan, J. G., \& Gutierrez, S. S. M. (2005). The impact of customer relationship marketing on the firm performance: a Spanish case. Journal of Services Marketing, 19(4), 234-244. http://dx.doi.org/10.1108/08876040510605262

Ketikidis, P. H., Koh, S. C. L., Dimitriadis, N., Gunasekaran, A., \& Kehajova, M. (2008). The use of information systems for logistics and supply chain management in South East Europe: current status and future direction. The International Journal of Management Science, OMEGA 36(4), 592-599. http://dx.doi.org/10.1016/j.omega.2006.11.010 
Koh, S. C. L., Demirbag, M., Bayraktar, E., Tatoglu, E., \& Zaim, S. (2007). The impact of supply chain management practices on performance of SMEs. Industrial Management \& Data Systems, 107(1), 103-124. http://dx.doi.org/10.1108/02635570710719089

Lagrosen, S. (2005). Customer involvement in new product development: a relationship marketing perspective. European Journal of Innovation Management, 8(4), 424-436. http://dx.doi.org/10.1108/14601060510627803

Lee, H. L., \& Whang, S. (2000). Information sharing in a supply chain. International Journal of Technology Management, 20(3-4), 373-387.

Leverin, A., \& Liljander, V. (2006). Does relationship marketing improve customer relationship satisfaction and loyalty? International Journal of Bank Marketing, 24(4), 232-251. http://dx.doi.org/10.1108/02652320610671333

Li, S., \& Lin, B. (2006). Accessing information sharing and information quality in supply chain management. Decision Support Systems, 42(3), 1641-1656. http://dx.doi.org/10.1016/j.dss.2006.02.011

Li, S., Ragu-Nathan, B., Ragu-Nathan, T. S., \& Subba Rao, S. (2006). The impact of supply chain management practices on competitive advantage and organisational performance. The International Journal of Management Science, OMEGA 34(2), 107-124. http://dx.doi.org/10.1016/j.omega.2004.08.002

Li, S., Subba Rao, S., Ragu-Nathan, T. S., \& Ragu-Nathan, B. (2005). Development and validation of a measurement instrument for studying supply chain management practices. Journal of Operations Management, 23(6), 618-641. http://dx.doi.org/10.1016/j.jom.2005.01.002

Meir, R. L., Williams, M. R., \& Singley, R. B. (2004). Supply chain management: strategic factors from the buyers' perspective. Journal of Industrial Technology, 20(2).

Mello, J. E, \& Stank, T. P. (2005). Linking firm culture and orientation to supply chain success. International Journal of Physical Distribution \& Logistics Management, 35(8), 542- 554. http://dx.doi.org/10.1108/09600030510623320

Mentzer, J. T. (2004). Fundamentals of supply chain management: twelve drivers of competitive advantage. Thousand Oaks, CA: Sage Publications, Inc.

Min, S., \& Mintzer, J. T. (2004). Developing and measuring supply chain concepts. Journal of Business Logistics, 25(1), 63-99.

Ngai, E. W. T. (2005). Customer relationship management research (1992-2002): an academic literature review and classification. Marketing Intelligence \& Planning, 23(6), 582-605. http://dx.doi.org/10.1108/02634500510624147

OECD (2006). The SME financing gap, volume 1, theory and evidence. OECD Publishing.

Osarenkhoe, A., \& Bennani, A-E. (2007). An exploratory study of implementation of customer relationship management strategy. Business Process Management Journal, 13(1), 139-164. http://dx.doi.org/10.1108/14637150710721177

Peng, M. W. (2009). Global business. Canada: South-Western Cengage Learning.

Power, D. (2005). Supply chain management integration and implementation: a literature review. Supply Chain Management: An International Journal, 10(4), 252-263. http://dx.doi.org/10.1108/13598540510612721

Quayle, M. (2003). A study of supply chain management practice in UK industrial SMEs. Supply Chain Management: An International Journal, 8(1), 79-86. http://dx.doi.org/10.1108/13598540310463387

Ravald, A., \& Gronroos, C. (1996). The value concept and relationship marketing. European Journal of Marketing, 30(2), 19-30. http://dx.doi.org/10.1108/03090569610106626

RMK-10. (2011). The 10th Malaysia Plan, 2011-2015. Kuala Lumpur, Malaysia.

Robb, D. J., Xie, B., \& Arthanari, T. (2008). Supply chain and operations practice and performance in Chinese furniture manufacturing. International Journal of Production Economics, 112(2), 683-699. http://dx.doi.org/10.1016/j.ijpe.2007.04.011

Sandberg, E., \& Abrahamsson, M. (2010). The role of top management in supply chain management practices. International Journal of Retail \& Distribution Management, 38(1), 57-69. http://dx.doi.org/10.1108/09590551011016331

Sari, K. (2007). Exploring the benefits of vendor managed inventory. International Journal of Physical Distribution \& Logistics Management, 37(7), 529-545. http://dx.doi.org/10.1108/09600030710776464

Sekaran, U. (2003). Research methods for business: a skill-building approach. Canada: John Wiley \& Sons.

Spath, D., \& Baumeister, M. (2001). Synchronisation of material flow and assembly in hybrid and modular 
systems. Assembly Automation, 21(2), 152-157. http://dx.doi.org/10.1108/01445150110388504

Spekman, R. E., Kamauff Jr., J. W., \& Myhr, N. (1998). An empirical investigation into supply chain management: a perspective on partnership. Supply chain Management, 3(2), 53-67. http://dx.doi.org/10.1108/13598549810215379

Storbacka, K., Strandvik, T., \& Gronroos, C. (1994). Managing customer relationships for profit: the dynamics of relationship quality. International Journal of Service Industry Management, 5(5), 21-38. http://dx.doi.org/10.1108/09564239410074358

Tan, K. C. (2002). Supply chain management: practices, concerns, and performance issues. Journal of Supply Chain Management, 38(1), 42-53. http://dx.doi.org/10.1111/j.1745-493X.2002.tb00119.x

Thakkar, J., Kanda, A., \& Deshmukh, S. G. (2009). Supply chain management for SMEs: a research introduction. Management Research News, 32(10), 970-993. http://dx.doi.org/10.1108/01409170910994178

Thoo, A-C., Huam, H-T, Md Yusoff, R., \& Rasli, A. (2010). A proposed conceptual model of determinants of supply chain performance in the Malaysian electronics manufacturing services (EMS) industry. International Journal of Business and Social Science, 1(1), 137-144.

Tracey, M., Fite, R. W., \& Sutton, M. J. (2004). An explanatory model and measurement instrument: a guide to supply chain management research and applications. American Journal of Business, 19(2), 53-69. http://dx.doi.org/10.1108/19355181200400012

Tumala, V. M. R., Philips, C. L. M., \& Johnson, M. (2006). Assessing supply chain management success factors; a case study. Supply Chain Management: An International Journal, 11(2), 179-192. http://dx.doi.org/10.1108/13598540610652573

UPS - United Parcel Services. (2008). UPS reveals Asia business monitor survey findings. [Online] Available: http://www.ups.com (January 30, 2011)

Uusipaavalniemi, S., \& Juga, J. (2009). Information integration in maintenance services. International Journal of Productivity and Performance Management, 58(1), 92-110. http://dx.doi.org/10.1108/17410400910921100

Valsamakis, V. P., \& Sprague, L. G. (2001). The role of customer relationships in the growth of small- to medium-sized manufacturers. International Journal of Operations \& Production Management, 21(4), 427-445. http://dx.doi.org/10.1108/01443570110381354

Van Hoek, R., Chatham, R., \& Wilding, R. (2002). Managers in supply chain management, the critical dimension. Supply Chain Management: An International Journal, 7(3), 119-125. http://dx.doi.org/10.1108/13598540210436568

Vereecke, A., \& Muylle, S. (2006). Performance improvement through supply chain collaboration in Europe. International Journal of Operations \& Production Management, 26(11), 1176-1198. http://dx.doi.org/10.1108/01443570610705818

Wagner, B. A., Fillis, I., \& Johansson, U. (2003). E-business and e-supply in small and medium sized businesses. Supply Chain Management: An International Journal, 8(4), 343-54. http://dx.doi.org/10.1108/13598540310490107

Wang, Y., Lo, H. H. P., Chi, R., \& Yang, Y. (2004). An integrated framework for customer value and customer-relationship-management-performance: a customer-based perspective from China. Managing Service Quality, 14(2/3), 169-182. http://dx.doi.org/10.1108/09604520410528590

Williams, B. D., \& Tokar, T. (2008). A review of inventory management research in major logistics journals: themes and future directions. The International Journal of Logistics Management, 19(2), 212-232. http://dx.doi.org/10.1108/09574090810895960

Williamson, E. A., Harrison, D. K., \& Jordan, M. (2004). Information systems development within supply chain management. International Journal of Information Management, 24, 375-385. http://dx.doi.org/10.1016/j.ijinfomgt.2004.06.002

Wong, C. Y., Arlbjorn, J. S., \& Johansen, J. (2005). Supply chain management practices in toy supply chains. Supply Chain Management: An International Journal, 10(5), 367-378. http://dx.doi.org/10.1108/13598540510624197

World Employment Report. (2004-05). Employment, productivity and poverty reduction. Geneva: International Labour Organization 2001.

Xu, Y., Yen, D. C., Lin, B., \& Chou, D. C. (2002). Adopting customer relationship management technology. Industrial Management \& Data Systems, 102(8), 442-452. http://dx.doi.org/10.1108/02635570210445871 
Yu, M-M., Ting, S-C., \& Chen, M-C. (2010). Evaluating the cross-efficiency of information sharing in supply chains. Expert Systems with Applications, 37(4), 2891-2897. http://dx.doi.org/10.1016/j.eswa.2009.09.048

Yu, Z., Yan, H., \& Cheng. T. C. E. (2001). Benefits of information sharing with supply chain partners. Industrial Management \& Data Systems, 101(3), 114-119. http://dx.doi.org/10.1108/02635570110386625

Zhou, H., \& Benton Jr, W. C. (2007). Supply chain practices and information sharing. Journal of Operations Management, 25(6), 1348-1365. http://dx.doi.org/10.1016/j.jom.2007.01.009

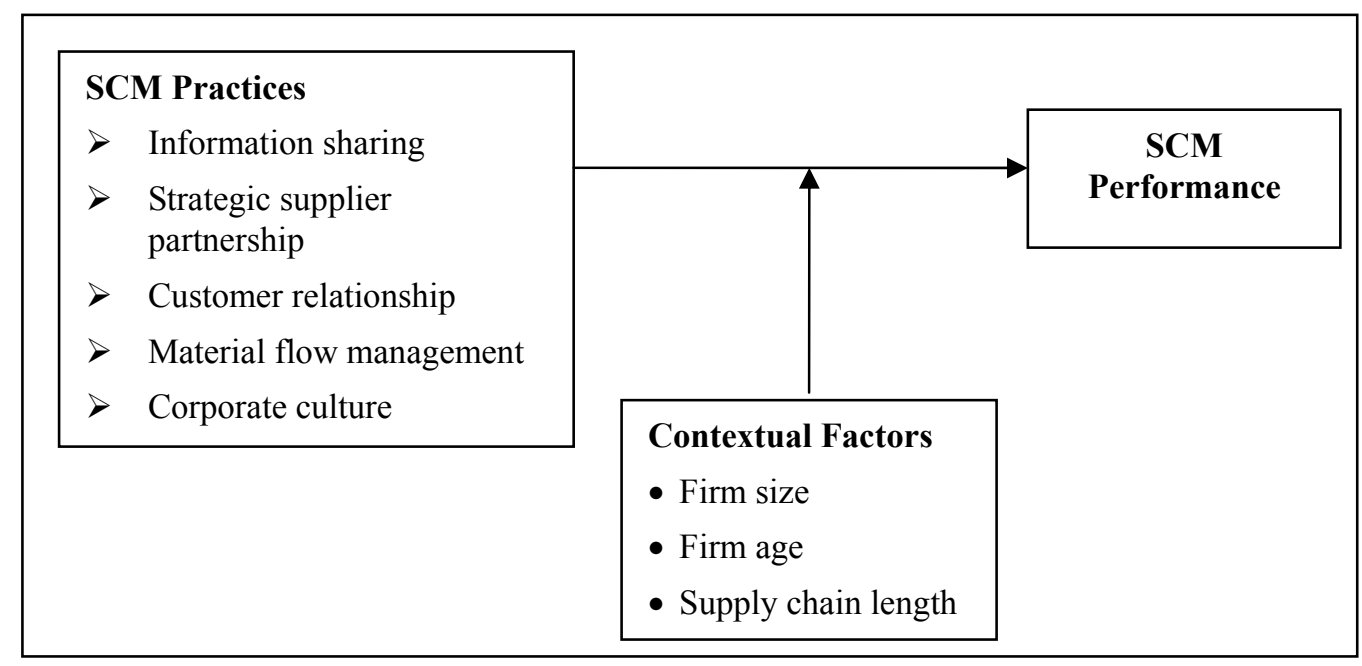

Figure 1. Proposed conceptual model 